\title{
Development of the thyroid gland of New-Zealand white rabbit
}

\author{
S. M. Soliman ${ }^{1}$, Tagreed M. Nabil ${ }^{1}$, A. Z. El-Kerdawy ${ }^{1}$, A. M. El-Bayomy ${ }^{2}$. \\ ${ }^{1}$ Department of Cytology and Histology, Faculty of Veterinary Medicine, Beni-Suef University, Beni-Suef, Egypt \\ ${ }^{2}$ Department of pharmacology, Faculty of Veterinary Medicine, Beni-Suef University, Beni-Suef, Egypt
}

The development of thyroid glands of New-Zeland rabbits was studied in 28 fetuses (10-30 days) and 28 rabbits (3 days-5 years). The thyroid premordia appeared at the $12^{\text {th }}$ day of gestation as 2 masses of cords and clumps of cells. The gland assumed the bilobed form with a narrow isthmus in between at the $18^{\text {th }}$ day. Small primitive follicles with narrow empty lumina appeared in 14-day-old fetuses. True follicles were recorded in 20-22 days old fetuses while colloid was seen in the lumina of the central follicles at the $24^{\text {th }}$ day. Light (C- or Parafollicular) cells were seen for the first time at the $12^{\text {th }}$ day. With development of the follicles, $\mathrm{C}$-cells appeared between the follicular cells and some of them come in contact with colloid. The ultimobranchial body (UBB) was observed in 20 days old fetuses close to the thyroid anlage and entered into its tissue at the $22^{\text {nd }}$ day. Later on, it gave thyroid-like follicles or ultimobranchial cysts. With the electron microscope (EM) follicular cells of earlydeveloping fetuses were not yet differentiated. They contained few ill-developed rough endoplasmic reticulum (rER) and mitochondria. The organelles became well developed and the cells started to secrete colloid in full term fetuses. The maximum rate of secretory activity was achieved in the glands of adult rabbits. Changes in the thyroid glands during the postnatal life up to 5 years of age (age of senility) were followed up and described.

The thyroid gland is considered one of the most important endocrine glands since its hormones regulate the metabolic activities of all body cells including its own cells, Also, the gland plays an important role in the prenatal development of mammals (Gorbman and Evans, 1943 and Hill, 2003). Owing to these functions and others, a lot of studies had been done on the thyroid gland of different species of mammals (Amin, 1963; Fahmy and Moustafa, 1965; ElGharbawy, 1986, Naser El-din et al., 1988; Okada et al., 1990; Elwan, 1994 and Elbargessy, 2001). Despite of this fact, rabbit thyroid gland received little attention. Therefore, the present investigation aimed to throw a spot of light on the development and structure of the thyroid gland in one of the economic breeds of rabbits; New-Zealand white rabbits.

\section{Materials and methods}

The thyroid glands of 28 rabbit fetuses (1030 days old) and of 28 male and female rabbits ( 3 days -5 years old) were fixed in $10 \%$ buffered neutral formalin and in Bouin's fluid. Early developing fetuses (upto16 days) were taken intact into fixatives. In other fetuses, the neck regions containing the thyroid glands were cut and fixed. After birth, the glands were dissected and fixed.

Serial paraffin sections of the thyroid glands were cut and stained with H\&E, Crossmon's trichrome, Gomori's reticulin and Weigert's elastic stain methods. The methods were done as described by Bancroft and Stevens (1982).

For transmittion electrom microscope (TEM) examination, the thyroid glands of 3 fetuses $(20,25$ and 29 days), one new born (7days), 3 adults (2, 4 and 6 months) and 2 senile rabbits ( 3 and 5 years) were fixed in $4 \%$ gluteraldhyde and post-fixed in $1 \%$ osmium tetraoxide. Epoxy-resin embedded sections were then cut. One micron thick sections were stained with toulidine blue and ultra thin sections were stained with uranyl acetate and lead acetate (Hayat 1989).

\section{Results}

Prenatal development. The thyroid gland was organized at the $12^{\text {th }}$ day of gestation. The glands of 12-18 days old fetuses were found to be quite similar in structure. The gland's premordia appeared as 2 oval masses of cells lying close to the tracheal analage (Fig. 1). The two lobes were connected together by a transverse band of the same tissue (Fig. 2). Both were formed of irregular cords and clusters of darkly stained cells with central spherical nuclei (Fig. 3). The cell aggregates and were supported by a delicate mesenchymal tissue. Some of the cells arranged themselves to form small vesicles with narrow 
empty lumina (Fig. 4). Development of the thyroid follicles began at the periphery of the gland at the $18^{\text {th }}$ day of gestation. Occasionally, large pale cells with large central euchromatic nuclei were seen lodging themselves peripheral to some of the follicular cells (Fig. 5). As a general role, many of the gland cells were observed at different stages of mitotic division.

Between 20-30 days of the prenatal life, significant changes could be observed in the developing glands. The thyroid follicles were progressively increased in number. Development of the follicles progressed centripetally. Also, the follicle became larger in size (Fig. 6) and was lined with cuboidal or columnar cells together with few parafollicular cells in between (Fig. 7). The latter were scattered singly or were aggregated as little groups of 2-3 cells. A very thin basement membrane surrounded the follicular and parafollicular cells together were found.

The follicular cells in 20-30 days old fetuses were considered to be inactive since their cytoplasm contained few ill developed rER, few ribosomes, small Golgi apparatus as well as few rounded mitochondria (Fig. 8).

Between the $24^{\text {th }}$ and $26^{\text {th }}$ days, the cells attained a secretory activity and a colloidal material appeared within some of the follicles (Fig. 9). The surrounding cells contained euchromatic nuclei and numerous welldeveloped rER, mitochondria and Golgi apparatus. Furthermore, short microvilli were seen projecting toward the colloid (Fig.10).

The connective tissue framework of the gland became pronounced. It was represented by a delicate fibrous capsule around each lobe of the gland and around the isthmus by a reticular net existing between the follicles (Fig. 11).

Close to the thyroid premordia of 20 day-old fetuses, aggregates in the form of cords and clumps of cells forming the premordia of the ultimobranchial body (Fig. 12). The cells contained central spherical nuclei surrounded by a darkly stained cytoplasm. Between the abovementioned cells, numerous lightly stained cells were frequently seen. Occasionally, follicles were observed to develop from ultimobranchial body cells (Fig. 13).

Postnatal development. The glands of newly born rabbits didn't vary greatly from those of full term fetuses. A fibrous capsule enveloped the gland's tissue and the follicles were surrounded by a vascular connective tissue mainly reticular fibers (Fig. 14). The structure of the thyroid follicle was also unchanged. They became larger in size. The presence of colloid became a common finding in many of follicles (Fig. 15). Furthermore, some vacuoles appeared within the colloid (Fig. 16). As development proceeds (up to 30 days of age), the capsule became thicker, the follicles were larger in size and more colloid was stored. The number of intracolloid vacuoles was also increased. Fig. (17) showed that the follicular cells contained numerous electron dense vesicles as well as lysosomes. In addition, adjacent cells were seen connected together by desmosomes.

The ultimobranchial body became smaller in size, embedded in the thyroid tissue and cystic structures were developed from its cells. The cysts were lined with simple cuboidal epithelium together with some light cells in between. Frequently the lumina of the cysts were irregular.

Adult rabbits at 2-6 months of age showed that their glands became well developed and attained their maximum activity.

Large follicles containing variable amounts of colloid was the predominant picture. The surrounding cells were usually cuboidal (Fig. 18) and their cytoplasm contained well-developed rER, well-developed Golgi saccules, numerous lysosomes as well as multiple electron dense secretory vesicle (Fig. 19). Fig. (20) showed that the vascularity of the gland was at its maximum. Colloid within follicle was found taken by the follicular cells. It appeared as minute droplets, scattered in the apical part of the cytoplasm (Fig. 21). Many empty vacuoles appear in the stored colloid. Parafollicular cells were still few in number but they became much larger in size. Some of these enlarged cells came in contact with the colloid (Fig. 22).

Senile rabbits (3-5 years old) showed some changes that could be attributed to the advance of age. The follicles were more or less irregular in shape, smaller in size and contained remnants of shrunken colloid. The follicular cells were usually flattened with darkly stained cytoplasm and flattened pyknotic nuclei. The parafollicular cells also showed variable degrees of degeneration (Fig. 23) but not as marked as in the follicular cells. Frequently, the thyroid follicles and some of the cysts that developed from the ultimobranchial body showed some degenerative changes. The cells were smaller in size, shrunken with dark cytoplasm and pyknotic 


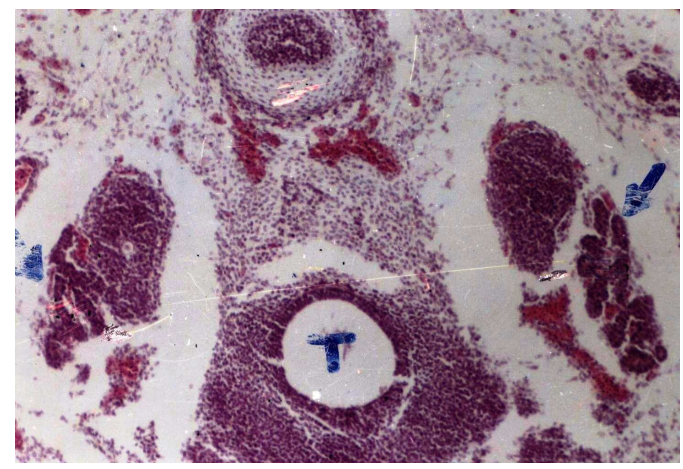

Fig. (1): Neck region of 12 day-old rabbit fetus showing the 2 oval masses of thyroid anlage (arrows) lying on the sides of the developing trachea $(T) . H \& E, x 100$.

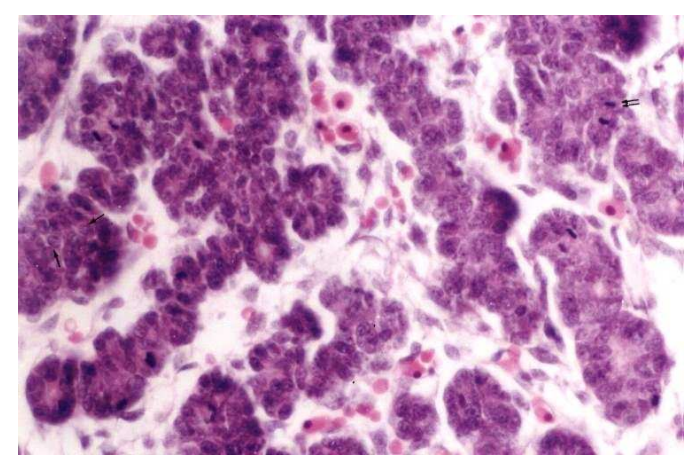

Fig. (3): Neck region of 12 days-old rabbit fetus showing that the thyroid premordia is formed of cords and clumps of cells supported by a delicate mesenchymal tissue. H\&E, x400.

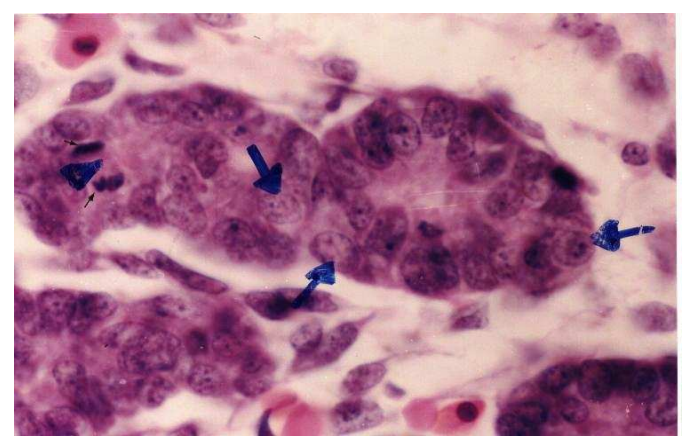

Fig. (5): Neck region of 14 days-old rabbit fetus showing 2 clusters of the thyroid premordia. Note the presence of light parafollicular cells (arrows) and one of the mitotically dividing follicular cells (arrow head). $H \& E$, x1000.

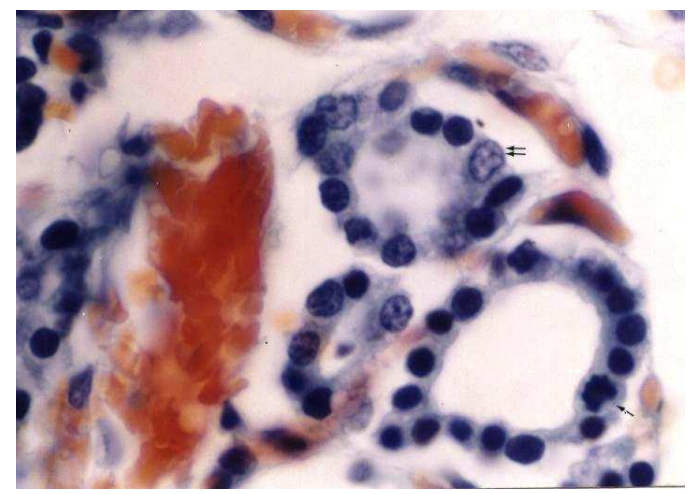

Fig. (7): Thyroid follicles of 25 days-old fetus showing few parafollicular cells (arrows) between the parafollicular cells. (Crossmon's trichrome stain), $\mathbf{x 1 0 0 .}$

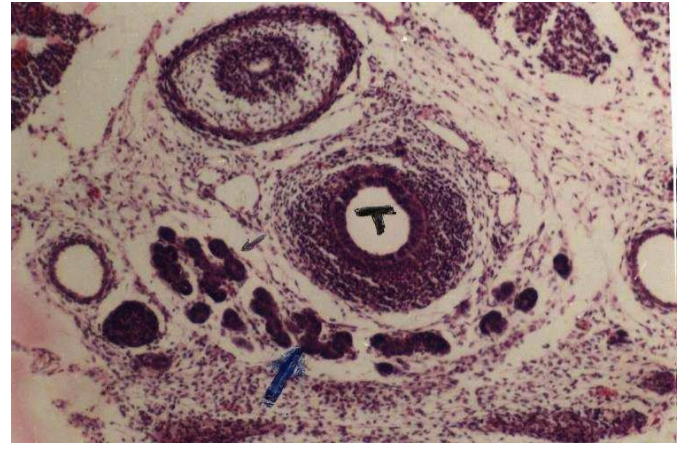

Fig. (2): Neck region of 18 day-old rabbit fetus showing a narrow cellular isthmus (arrow) in front of the developing trachea $(T) . H \& E, x 100$

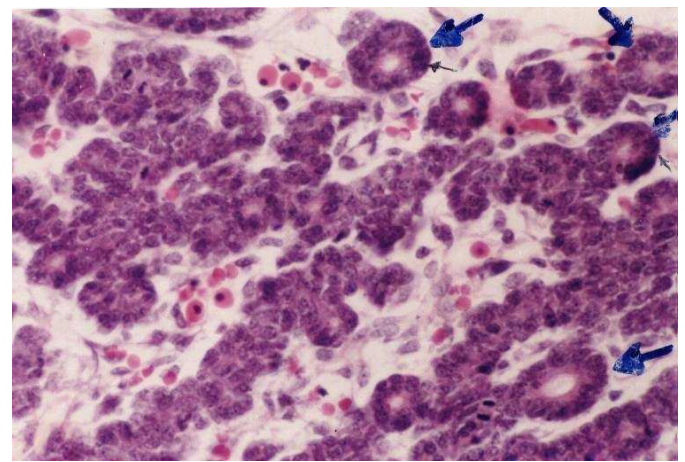

Fig. (4): Neck region of 14 days-old rabbit fetus showing the developing of some primitive follicles (arrows) at the periphery of the thyroid anlage. $H \& E$, $x 400$

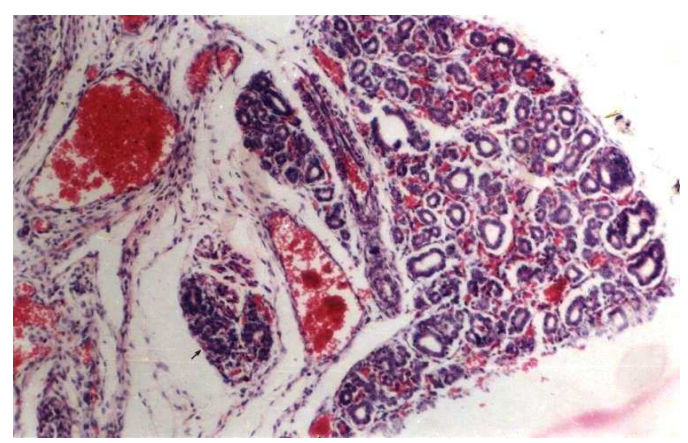

Fig. (6): Neck region of 20 days-old rabbit fetus showing Progressively increased number of developing thyroid follicles. H\&E, x100.

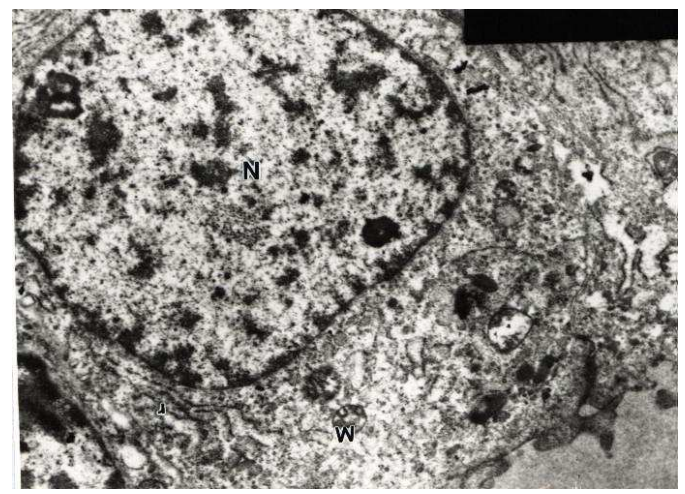

Fig. (8): Follicular cells of 20 days-old fetus showing few ill developed rER (R). nucleus (N) and few mitochondria (M). $\mathrm{x} 7600$. 


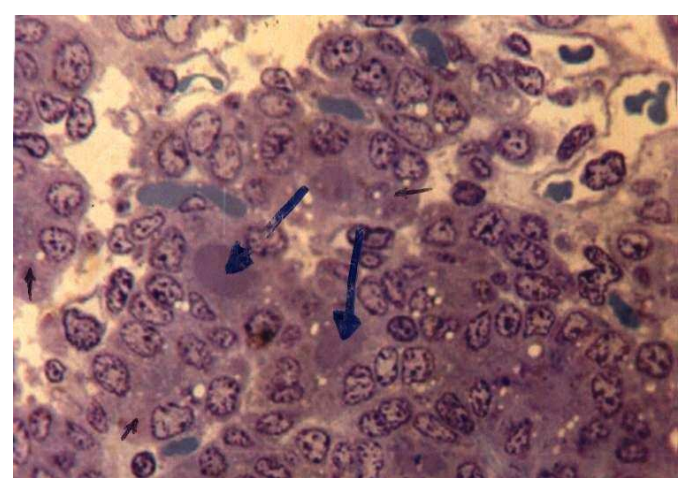

Fig. (9): Thyroid gland of 24 days-old fetus showing a colloid secretion within some of the follicles (arrows) toluidine blue, $\mathbf{x 1 0 0 0}$.

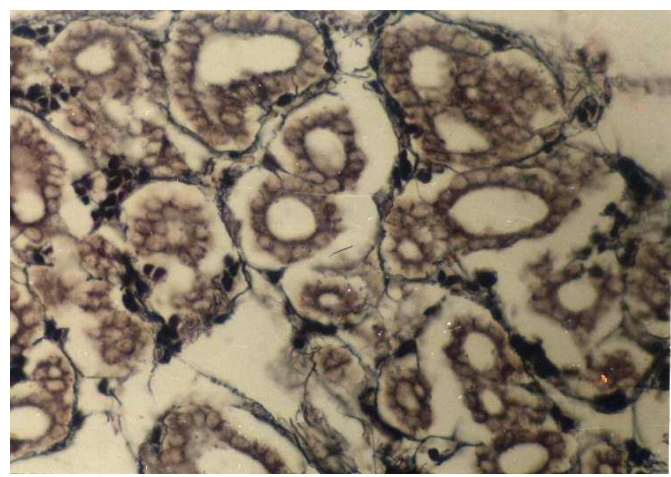

Fig. (11): Thyroid gland of 29 days-old fetus showing the reticular network between the follicle. Gomori's reticulin method, $\mathbf{x 4 0 0}$.

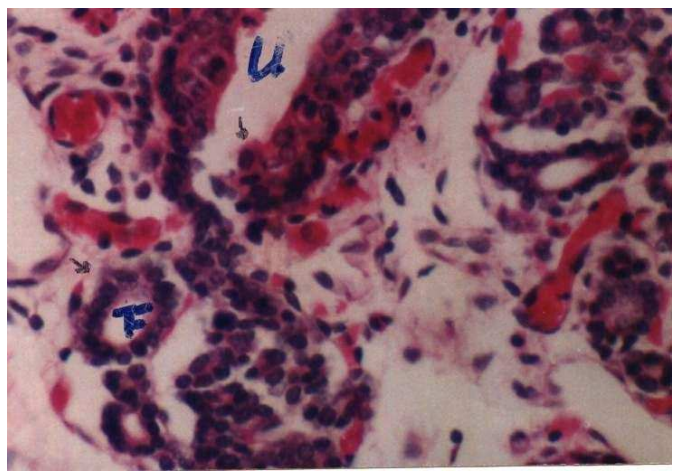

Fig. (13): Neck region of 30 days-old rabbit fetus showing development of some of the follicles (F) from the ulttimobranchial body (u) H\&E, x400.

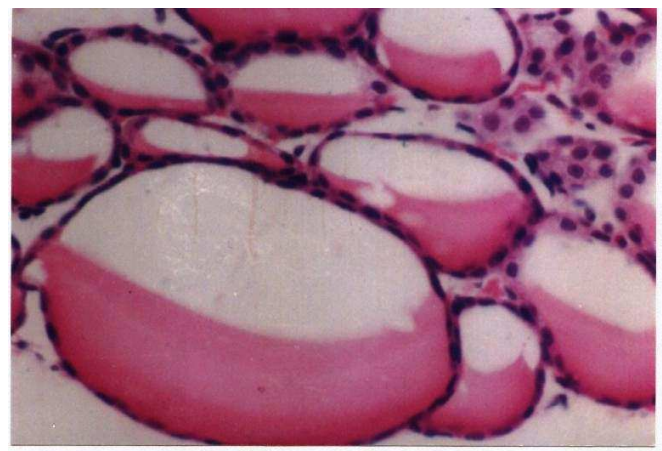

Fig. (15): Thyroid gland of 7 days-old rabbit showing that the follicles were larger and stored some colloid. H\&E, x400

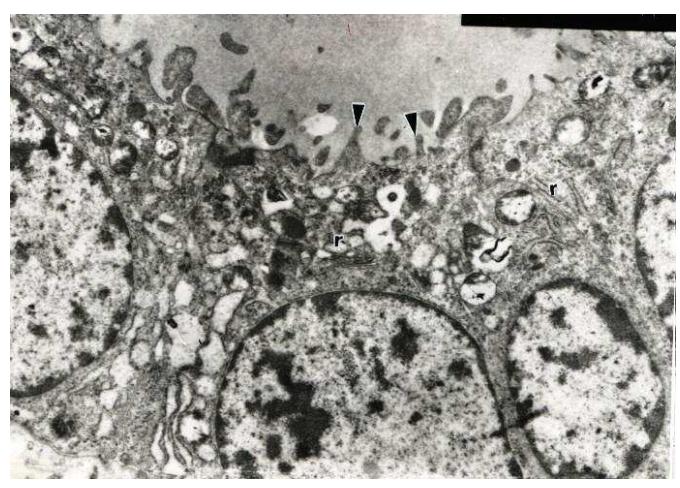

Fig. (10): Follicular cell of 25 days-old fetus showing numerous well-developed rER (r). microvilli were seen projecting toward the colloid (arrows). $\times 5000$.

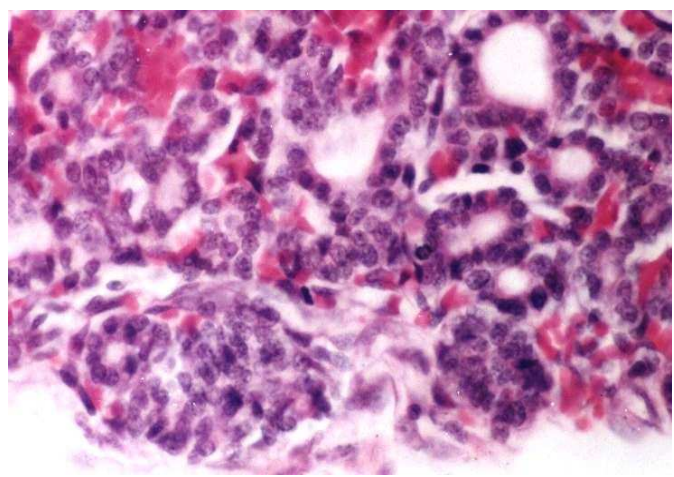

Fig. (12): Neck region of 22 days-old rabbit fetus showing that the ultimobranchial body (U) lying close to thyroid prERmordia (T). H\&E. x 400 .

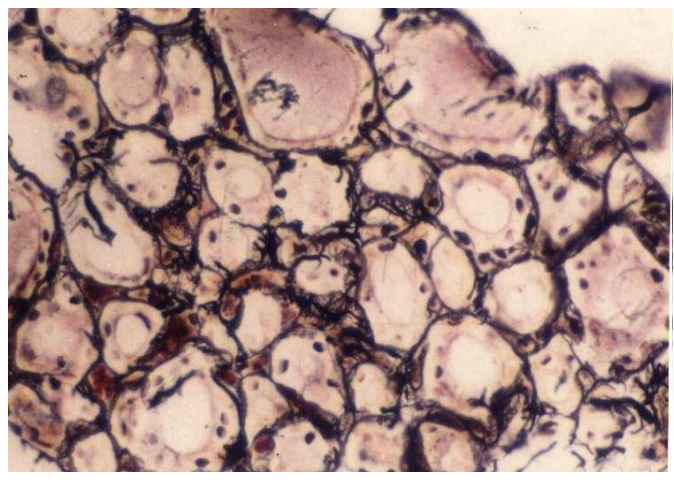

Fig. (14): Thyroid gland of one week-old rabbit showing the interstitial reticular stroma. Gomori's reticulin method, $\mathbf{x} 400$.

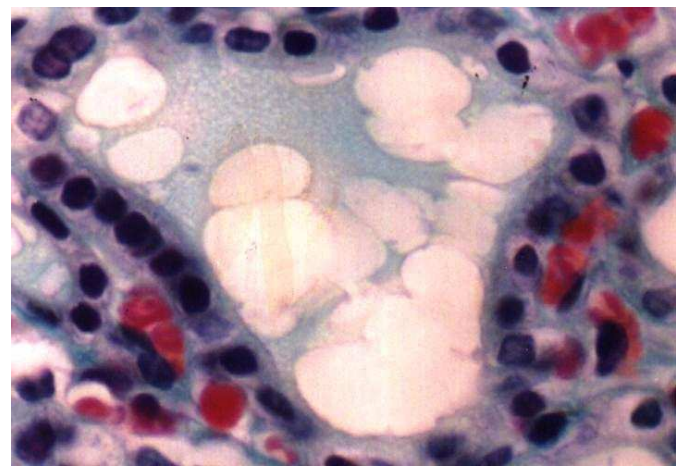

Fig. (16): Thyroid follicle of 2 weeks-old rabbit showing the presence of numerous vacuoles in the stored colloid. Crossmon's trichrome stain. $\mathbf{x 1 0 0 0}$. 


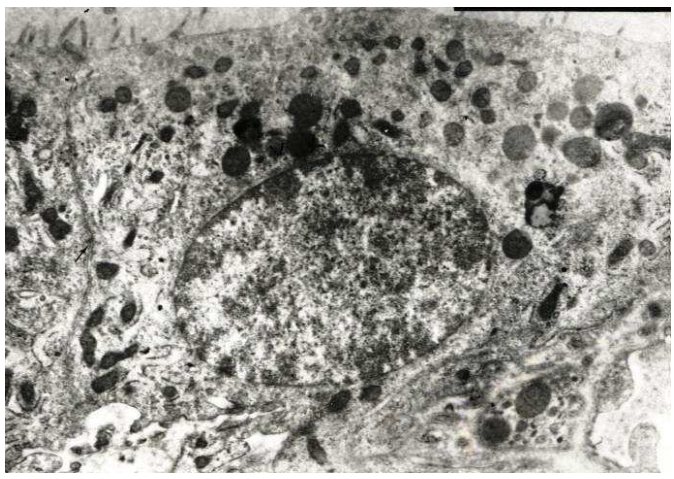

Fig. (17): Follicular cells of 7days-old rabbit showing numerous electron dense vesicle (V) and lysosome (L). Note the desmosome (D) (arrow) that connects the cell to the adjacent one. $\mathbf{x 7 6 0 0}$.

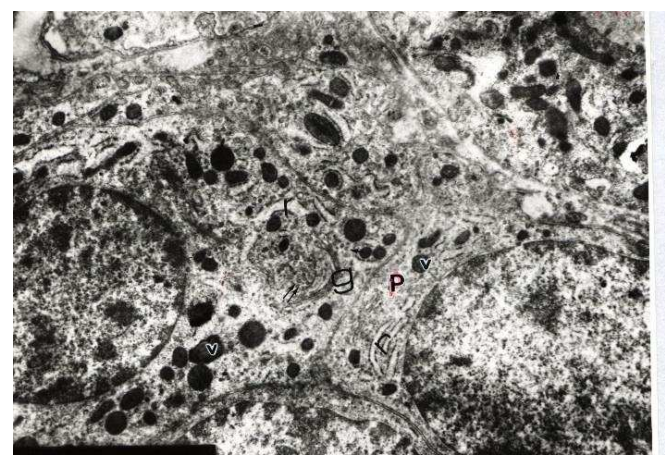

Fig. (19): Follicular cells of 4 months-old rabbit showing well developed rER (R), Golgi apparatus (G), lysosomes (L), and electron dense secretorv vesicles $(V)$ x 5000 .

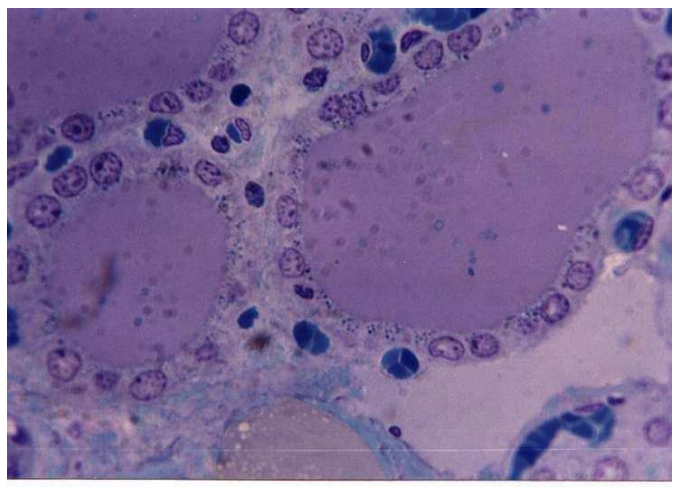

Fig. (21): Thyroid follicles of 6 months-aged rabbit showing the presence of minute colloid droplets in the apical cytoplasm of many follicular cells. Toludin blue, $\mathbf{x} 400$.

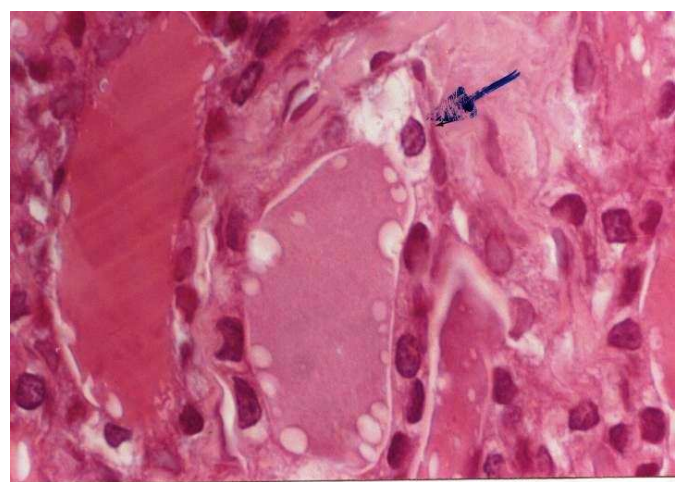

Fig. (23): Thyroid gland of a senile rabbit ( 5 years) showing hypertrophy and vacuolation of some of the parafollicular cells (arrow). H\&E, x1000.

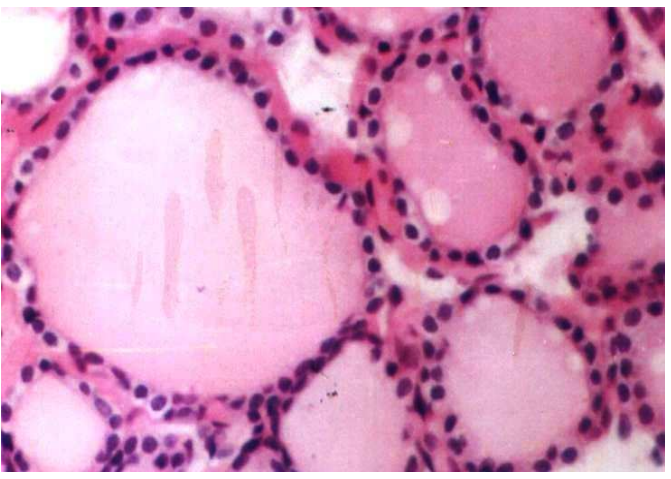

Fig. (18): Thyroid gland of one month-aged rabbit showing the well developed follicles. They were lined with simple cuboidal

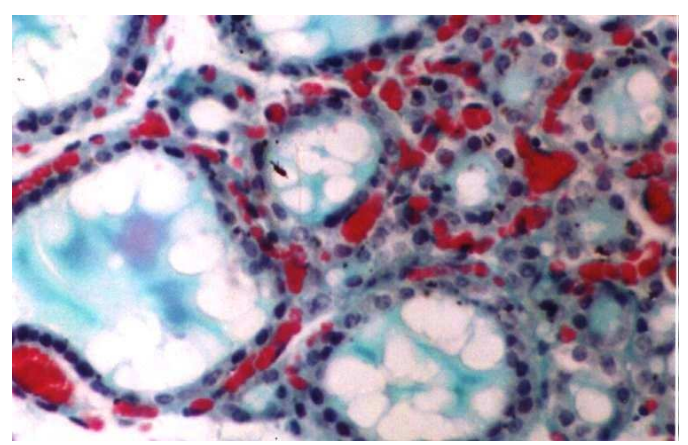

Fig. (20): Thyroid gland of 6 months-aged rabbit showing a vascular stroma between the well-developed active follicles. Crossmon's trichrome, $\mathbf{x 1 0 0 .}$

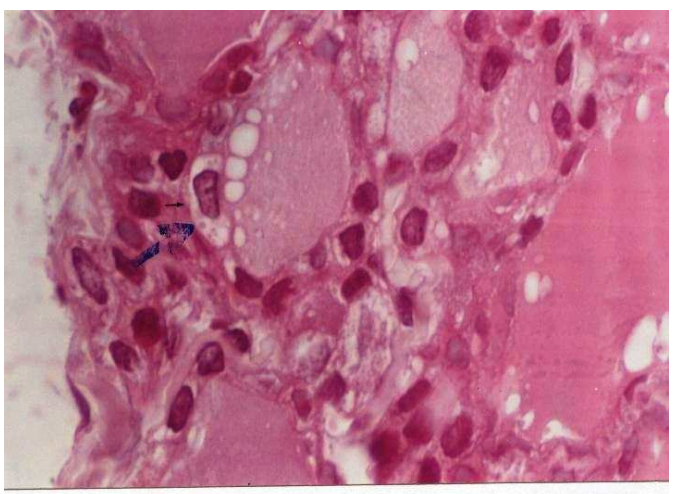

Fig. (22): Thyroid gland of 6 months-old rabbit showing enlarged parafollicular cells that come in contact with the colloid (arrows). H\&E, x1000.

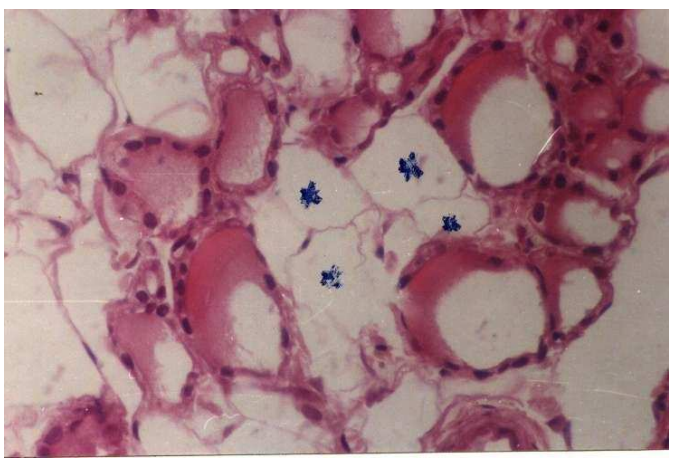

Fig. (24): Thyroid gland of a senile rabbit (5 years) showing shrinkage of the follicle and appearance of some adipocytes in the interstitial stroma H\&E, $\mathbf{x} 400$. 
nuclei. Sometimes these cystic structures contained aggregates of cell debris co-existed with many macrophages. Shrinkage of the thyroid follicles and decreased amount of colloid gave the chance to the interstitial stroma to increase in amount and some adipocytes to appear (Fig. 24).

\section{Discussion}

It is generally accepted that the thyroid gland was developed as ventral out pocketing from the foregut between the first and second branchial pouches. Its premordia was recorded in 9 daysold oppossum fetuses (Taniguchi et al., 1990) and in 10-17 days old rabbits (Waterman and Gorbman, 1956 and El-Shamaa, 1996). In the present investigation, the gland's anlage was demonstrated at the $12^{\text {th }}$ day of the rabbit's foetal life as 2 masses of thick irregular cords and as clumps of cells close to the tracheal premordia.

Rabbits seemed to be similar to other laboratory animals (Conde et al., 1992 and ElShammaa, 1996) and to domestic animals (Jordon et al., 1973 and Elwan, 1994) in that the thyroid glands are formed of follicles. Regarding their origin, 3 possible sites were suggested for the development of the thyroid follicles; thyroid premordial cells, ultimobranchial cells and by budding from pre existing follicles (Krause and Cutts, 1983; El-Gharbawy, 1986; Elwan, 1994 and El-Shammaa, 1996). The third postulation by (Isler et al., 1968) that the so-called budding was in fact tagential sectioning of the follicles was not accepted.

The development of the thyroid follicles was found to be interesting. In rabbits and rats (Mitskavitch, 1957), buffaloes (Fahmy and Moustafa, 1965) and camels (El-Gharbawy, 1986), the follicles began to develop in the periphery of the gland, and then extended centrally.

Primitive follicles with narrow empty lumina were demonstrated in 14 days-old rabbits fetuses. The cells were considered to be inactive since they contained few ill-developed rER, Golgi apparatus and mitochondria. The follicles became well developed in 20-22 days old fetuses and some of them contained a little amount of colloid at the $24^{\text {th }}$ day. Similar sequences in rabbits were recorded by (Waterman and Gorbman, 1956; El-Shammaa, 1996; Taniguchi et al., 1990), while follicles appeared in 15 days old fetuses of hamsters and started to secrete colloid 0-3 days after birth (Taniguchi et al., 1990). In domestic animals, the development of thyroid follicles and appearance of colloid was found to be variable (Mitskavitch, 1957 and Badawy et al., 1983). It might extend to 3 weeks prior to birth in dogs (Nunez and Gershon, 1975).

The activity of the follicular cells to synthesis and to secrete thyroglobulins (colloid) and to reabsorb colloid to secrete active hormones was taken in consideration. In the literature, it had been found that the secretory activity of the gland cells began during the latter stages of fetal development in animals having a long gestation period as camels and buffaloes and postnatally in animals having short gestation period as rabbits and rats (Hall and Kaun, 1942 and Mitskavitch, 1957). This generalization could not be easily accepted since colloid started to be seen within follicles in 24-26 days old rabbit fetuses. The maximum rate of secretory activity, however, was detected in glands of adult rabbit. During this period (2-6 months), colloid accumulated in the follicles and vacuoles appeared in the colloid. Bank (1993) considered the presence of vacuoles in the colloid as a sign of secretory activity. Furthermore, so many cells of the rabbit's follicular cells had been found to contain numerous minute droplets of colloid in their apical cytoplasm.

Data gained from the EM graphs indicated that cells were actively secreting. They contained all cytoplasmic organoids that could synthesize glycoprotein (thyroglobulins). Numerous well-developed rER, mitochondria and Golgi apparatus were observed. Furthermore, short microvilli could be observed projecting from the follicular cells toward the colloid.

The development of parafollicular cells was found to be variable among different animals. Cells were demonstrated in opposum after birth (Krause and Cutts, 1983), they were described as light cells in the fetuses of rabbits (El-Shammaa, 1996), rats (Conde et al., 1992), sheep (Jordon et al., 1973), buffaloes (Elwan, 1994) and camels (El-Gharbawy, 1986). In rabbits, the parafollicular cells were recorded for the first time between the thyroid cord cells and between the epithelial cells of the ultimobranchial body cells at the $12^{\text {th }}$ and $20^{\text {th }}$ days old fetuses, respectively.

It had been suggested that the parafollicular cells were derived from the ultimobranchial body (Roy and Saigal, 1986 and Harash, 1987), neural crest and then carried by the 
ultimobranchial body to the thyroid analage (Pearse and Polka, 1971) or were derived from the follicular cells which have lost contact with colloid (Sarker and Isler, 1963 and Boyd, 1964). The last hypothesis could not be accepted since so many cells were seen coming in contact with colloid. The last finding had been observed in the glands of many animals including rabbits (Roy and Yadava, 1975; Badawy et al., 1978; Ewis et al., 1982 and Yanani et al., 1982).

In 1990, Taniguchi and his co-workers stated that the UBB in hamster was derived from the $5^{\text {th }}$ pouch and fused with the thyroid in the $12^{\text {th }}$ day of gestation. In rabbits, the body was observed close to the thyroid anlage at the $20^{\text {th }}$ day as a compact cell masses surrounded by a highly vascularized connective tissue. At the $22^{\text {th }}$ day, the body became completely embedded in the thyroid tissue and at the $26^{\text {th }}$ day, it was transformed into cystic structures similar to those which were derived from the thyroid anlage. Formation of thyroid follicles from the UBB was found to be a common finding in many other animals as rats (Conde et al., 1992), sheep (Jordon et al., 1973), buffaloes (Elwan, 1994) and camels (El-Gharbawy, 1986).

UBB as well as thyroid follicles in senile rabbits underwent cystic degeneration and numerous cell debris as well as many macrophage cells were recorded in their lumina. Similar degenerative changes were also demonstrated in the UBB of many other animals as rats (Conde et al., 1992), dogs (Booth and Gloshal, 1978) and buffaloes (Elwan, 1994).

\section{References}

Amin, S. O. (1963): Prenatal development of some endocrine glands (the thyroid gland of camel embryo) .M. Sc. Thesis, Ain Shams Univ., Fac. Agricult., Anim. Prod. Dept., Egypt.

Badawy, Y. H.; El-keshawy, A. H.; Ghallab, A. M.; Abdou, M. and Selim, A. A. (1978): Histological and histochemical studies on the prenatal development of the thyroid gland of camel (Camelus dromedarius). Egypt. J. Histol., 6 (2): 365-375.

Bancroft, J. D. and Stevenes, A. (1982): Theory and practice histological technique. $2^{\text {nd }}$ ed. ChurchillLivingstone. Edinburgh, London, Melbourne \& New York.

Bank, W. J. (1993): Applied veterinary histology. $3^{\text {rd }}$ ed. Mosby Year Book. St. Louis, Baltimore, Boston, Chicago, London, Philadelphia, Sydney \&Toronto.

Booth, K. K. and Gloshal, N. G. (1978): A typical thyroid follicles arising from an ultimobranchial like cyst in a post natal canine thyroid gland. Acta Anat., 102: 405-410.

Boyd, J. D. (1964): Development of the human thyroid gland. $3^{\text {rd }}$ ed. Rosalind pitt rivers and W.R. Trotter, Butterworth and Co., London.

Conde, E.; Moreno, A. M.; Martine-Lacave, I.; Fernandez, A. and Galera, H. (1992): Immuno cytochemical study of the ultimobranchial tubules in Wister rats. Anat. Histol. Embryol., 21: 94-100.

El-Bargessy, G. A. (2001): The thyroid gland of lactating she camel (Camelus dromedarius), light and fine structure. Banha Vet. Med. J., 12 (2): 27-48.

El-Gharbawy, S. M. S. (1986): Developmental studies on the thyroid gland of one-humped camel (Camelus dromedarius). M.V.Sc. Thesis. Fac. Vet. Med., Cairo Univ., Egypt.

El-Shammaa, A. M. (1996): Developmental studies on the thyroid gland of rabbit. Egypt. J. Anat., 19 (1): 207-227.

Elwan, I. F. (1994): Developmental studies on the thyroid gland of buffalo (Bos bubalis L.). M.V.Sc.Thesis. Fac. Vet. Med., Zag. Univ., Egypt.

Ewais, M. S.; Bareedy, M. H.; El-keshawy, A. H.; and Abdou, M. (1982): Histological and histochemical studies of the thyroid gland of baladi goat with special reference to age variation. Egypt .J. Histol., (2): 193-197.

Fahmy, M. and Moustafa, M. S. (1965): prenatal development of the thyroid gland of buffalo embryos (Bos bulbalis L.). Egypt Vet. Med. J., 11: 155-167.

Gorbman, A. and Evans, H. M. (1943): Beginning of function in the thyroid gland. Am. J. Anat., 73: 298-314.

Hall, A. R. and Kaun, H. W. (1942): Anatomical and physiological studies on the thyroid gland of albino rat. Anat. Rec., 84: 221-239.

Harash, H. R. (1987): Mixed follicle of human thyroid gland. Acta Anat., 129: 27-30.

Hayat, N. A. (1989): Principles and techniques of electron microscopy, biological application $.3^{\text {rd }}$ ed. Aspen Publishers Inc., Rockville, Maryland.

Hill, M. A. (2003): The human embryology. Cell Bio. Lab. J., 8: 681-687.

Isler, H.; Sarker, S. K.; Thomposon, B. and Tonkin, R. (1968): The architecture of the thyroid gland: A 3 dimensional investigation. Anat. Rec., 161: 325-326.

Jordon, R. F.; McFarlane, R. and scothorne, R. J. (1973): An electron microscopic studies of the histogenesis of the ultimobranchial body of the C-cell system in the sheep. J. Anat., 114: 115-136.

Krause, W. J. and Cutts, J. H. (1983): Post-natal development of the thyroid gland in the opposum (Didelphis Virginana ). Acta Anat., 116: 322-338.

Mitskavitch, M. C. (1957): Glands of internal secretion in the developing birds and mammal embryoes. Publication of the academy of science of USSR., Moscow.

Naser El-din, R. A.; Youssef, A. A.; Mahmoud, M. F. and Ibrahim, I. A. (1988): Thyroid hormones, glucose, total lipids and total protein in blood stream during reproductive cycle in cattle. Anim. physiol., 59: 167-170.

Nunez, E. A. and Gershon, M. D. (1975): Appearance and disappearance of multi-ciliated follicular cells during development of the dog's thyroid gland. Anat. Rec., 184: 133-146.

Okada, H. M.; Matsukawa, K.; Okgya, N.; Yokota, H.; Taniyama, H. and Yuasa, G. (1990): Immunohistocytochemical demonstration of parafollicular C-cell in sheep thyroid and parathyroid gland. Jap. J. Vet. Med. Sci., 52 (4): 879-882.

Pearse, A. G. and Polak, M. (1971): Cytochemical evidence for the neural crest origin of mammalian C-cells. Histochem., 27: 96-102.

Roy, K. S. and Saigal, R. P. (1986): Histo-morphological and enzymic observation of the ultimobranchial follicle of the sheep thyroid. Indian. j. Anim. Sci., 56 (10): 1013-1016. Roy, K. S. and Yadava, R. C. P. (1975): Histological and certain Histo-chemical studies on the thyroid gland of the 
Asciatic water buffalo (Bubalus bubalis). Indian J. Anim. Sci., 45 (4): 201-208.

Sarker, S. K. and Isler, H. (1963): Origin of the light cell of the thyroid gland in rat. Endoc., 73: 199-240.

Taniguchi, K.; Shutoh, Y. and Mikami, S. (1990): Immuno-histochemical studies on the development of endocrine cells in the thyroid gland in the golden hamster. Jap. J. Vet. Sci., 52 (1): 19-27.

Waterman, A. J. and Gorbman, A. (1956): Development of the thyroid gland of rabbit. J. Exp. Zool., 132: 509-538.

Yanani, T.; Tateyama, S.; Dai-Noska, A. and Aschizaw, H. (1982): Some observations on the parafollicular (C) cells in the equine thyroid. Jap. J. Vet. Sci., 44: 511-516. 